\title{
FACILITATED TUCKING EFFECTIVE TO PAIN RELIEF ON THE PRETERM INFANTS IN PERINATAL UNIT IN JAKARTA
}

\author{
Eva Oktaviani $^{1 *}$, Yeni Rustina ${ }^{2}$, Defi Efendi ${ }^{2}$ \\ 1. Nursing Major of Health Polytechnic of Ministry of Health Lubuklinggau, Palembang, 31626, Indonesia \\ 2. Faculty of Nursing Universitas Indonesia, Depok 16424, Indonesia \\ *E-mail: nersevaoktaviani@gmail.com
}

\begin{abstract}
The majority of preterm infants require a long period of hospitalization in intensive care units, which often necessitates those undergoing painful procedures, including blood collection. This study aims to identify the effectiveness of facilitated tucking on pain responses, including physiological parameters and the duration of crying during blood collection. The study design is quasi-experimental, employing a nonequivalent control group pretest-posttest approach. The study involves 40 infants, selected by the consecutive sampling technique and assigned into two groups: an intervention group $(n=20)$, which received facilitated tucking during blood collection, and a control group $(n=20)$, which did not receive facilitated tucking. The General Linear Model+post hoc, Mann-Whitney, and independent t-test were applied to analyze the data. The results suggest that there was a significant difference in the mean of the pulse, oxygen saturation, and duration of crying between the two groups during blood collection. The duration of crying in the intervention group was shorter than in the control group. Facilitated tucking was effective in relieving pain and the duration of crying during blood collection, and could be implemented as part of the developmental care process to promote pain management in infants.
\end{abstract}

Keywords: developmental care, facilitated tucking, pain, preterm infants

\begin{abstract}
Abstrak
Mayoritas bayi prematur akan mengalami perawatan yang lama di ruang intensif, sehingga terpapar sejumlah prosedur menyakitkan berulang yang menimbulkan respon nyeri salah satunya pengambilan darah. Tujuan dari penelitian ini untuk mengidentifikasi pengaruh penerapan facilitated tucking terhadap respon nyeri berupa parameter fisiologis dan lama menangis selama dilakukan pengambilan darah. Desain penelitian adalah quasi experimental dengan nonequivalent control group pretest-posttest design. Empat puluh bayi pada sampel penelitian dibagi menjadi dua kelompok; kelompok intervensi $(n=20)$ dengan facilitated tucking dan kelompok kontrol $(n=20)$ tanpa facilitated tucking, diambil secara consecutive sampling. Analisis menggunakan uji General Linear Model+post hoc, Mann-Whitney, dan Independent TTest. Ada perbedaan signifikan rerata frekuensi nadi, saturasi oksigen, dan lama menangis antara kedua kelompok selama pengambilan darah. Lama menangis pada kelompok intervensi menjadi lebih singkat. Facilitated tucking efektif mengurangi nyeri dan lama menangis selama pengambilan darah. Facilitated tucking dapat diterapkan sebagai bagian dari asuhan perkembangan untuk mendukung program pengendalian nyeri pada neonatus.
\end{abstract}

Kata kunci: asuhan perkembangan, bayi prematur, facilitated tucking, nyeri

\section{Background}

Preterm infants require long periods of special care in neonatal intensive care units due to the prematurity of their body functions and anatomy (Jaberi \& Raksana, 2017; Johnston, Fernandes,
\& Campbell-Yeo, 2011; Lawn et al., 2013). The condition puts babies at risk from distress and from the various painful procedures they need to undergo as part of routine care (Brummelte, et al., 2012). Arterial or venous blood collection and heel pricks are among the procedures which 
they frequently undergo during their hospital stay (Johnston et al., 2011). Repeated invasive procedures are pain-provoking stimuli. Pain is acute stress, which may lead to short and longterm complications as it occurs during critical periods (Kostovic \& Judas, 2010; Marchant, 2014; Page, 2004). Short-term complications include changes in physiological parameters (tachycardia, desaturation and tachypnea), behaviors and metabolism (Kostovic \& Judas, 2010). Long-term complications from persistent and uncontrolled pain include the altered development of the central nervous system, heightened pain sensitivity, impaired regulation of stress hormones (cortisol), and changes in the hypothalamus-pituitary-adrenal (HPA) axis (Walker, 2013). Another long-term complication is immunocompromised (Page, 2004).

Preterm infants have a mature pain pathway; however, they perceive pain for a longer period due to the immaturity of their descending pathway of pain (Hatfield, 2014). Therefore, it is essential to implement pain management to enhance infants' ability to cope with it and to promote their growth and development. The extent and complexity of consequences resulting from hospitalization stress require nurses to take more effective and efficient non-pharmacological approaches with fewer side effects. The pharmacological approach to relieving pain in infants is reported to result in harmful side effects, including respiratory depression, apnea, bradycardia, hypotension, desaturation, airway obstruction, and hypersalivation (Lago et al., 2009).

Non-pharmacological approaches that have been proven to be effective in relieving pain and stress in preterm infants include non-nutritive sucking, kangaroo mother care, provision of oral sucrose, music therapy, swaddling, and facilitated tucking (Martin, Dias, Enumo, \& de Paula, 2013). A study by Reyhani, Aemmi, Mohebbi, and Boskabadi (2014) reported that facilitated tucking during venipuncture might reduce pain responses in preterm infants, as indicated by the shorter duration of crying in the intervention group. The facilitated tucking position is des- cribed as a sub-type of the nesting procedure, positioning infants in the middle or closer by holding their upper and lower extremities in a flexion position in both of the examiner's hands (Kucukoglu, Kurt, \& Aytekin, 2015).

Behaviors demonstrated by infants in pain include avoidance (infants withdraw their extremities away from pain stimuli), aggression (tachycardia, desaturation, and increased muscle tone), postural or expression changes, and alarm (crying) (Bellieni, 2012). Developmental care in neonatal care units aims to reduce physiological and psychological distress in order to promote nerve development in preterm infants. This care includes positioning and touch, such as facilitated tucking, which provides comfort throughout a painful procedure (Fernandes, Campbell-Yeo, \& Johnston, 2011).

In Indonesia, no studies have addressed the application of facilitated tucking in preterm infants with non-invasive ventilation, and its impact on two pain responses during blood collection, namely physiological parameters and behavior, thus emphasizing the need conduct such research. This study aims to identify the effectiveness of facilitated tucking on relieving pain by evaluating two pain responses, namely heart rate and oxygen saturation, and duration of crying in preterm infants during blood collection.

\section{Method}

The study design was quasi-experimental, employing a nonequivalent control group pretestposttest approach. The study involved 40 preterm infants admitted to several hospitals in Jakarta, all of whom were selected through the consecutive sampling technique and assigned to intervention and control groups which each comprised 20 infants. The inclusion criteria included preterm infants with a gestational age of 28-36 weeks and non-invasive ventilation, and who were undergoing arterial or venous blood collection; the exclusion criteria included infants with congenital and neurological defects, those with hemodynamic instability, and infants who 
had been prescribed with analgetic or sedative medication.

The intervention group was given facilitated tucking three minutes prior to the puncture, during the puncture, and three minutes following it, while the control group was provided with standard care during blood collection. Facilitated tucking was applied by facilitating infants in a physiological flexion position by fixing one hand on the posterior part of their head and hand, while the other hand fixating the buttocks and flexed the extremities. This position resembles a flexed fetal-type position in the womb.

Pain responses were evaluated by assessing physiological parameters including alteration in pulse rate and oxygen saturation, which were documented at their highest points before, during, and after the puncture, and behavioral response (crying duration), whose length was measured in seconds by a stopwatch. The evaluation of the physiological parameters and crying duration was compared with that of the control group, who were provided with standard care (without facilitated tucking).

The study was granted administrative approval and conducted by complying with research ethics. Ethical clearance was issued by the Ethical Committee of the Faculty of Nursing of Universitas Indonesia.

\section{Results}

The findings are presented based on the type of analysis. The majority of the infants were male (67.5\%), applied with CPAP (Continuous Positive Airway Pressure) (62.5\%), with an average birth weight of 1411.6 grams, and an average weight of 1481.6 grams during the data collection. The average gestational age was 31.8 weeks and the average age was 10.1 days. The test of homogeneity revealed that both groups were homogeneous. The participant characteristics are shown in Table 1.

Figure 1 shows that the control group, who were not provided with facilitated tucking, had their

Table 1. Participant Characteristics in the Intervention and Control Groups

\begin{tabular}{|c|c|c|c|c|c|}
\hline \multirow{3}{*}{ Characteristic } & & \multirow[b]{2}{*}{ Total } & \multicolumn{2}{|c|}{ Group } & \multirow{3}{*}{$p, x^{2}$} \\
\hline & & & Facilitated Tucking & $\begin{array}{c}\text { No Facilitated } \\
\text { Tucking }\end{array}$ & \\
\hline & & n (\%) & n (\%) & $\mathbf{n}(\%)$ & \\
\hline \multirow[t]{2}{*}{ Gender } & Male & $27(67.5)$ & $14(70)$ & $13(65)$ & 1,000 \\
\hline & Female & $13(32.5)$ & $6(30)$ & $7(35)$ & \\
\hline \multirow[t]{5}{*}{ Mechanical ventilation } & NIV & $3(7.5)$ & $1(5)$ & $2(10)$ & 0.428 \\
\hline & CPAP & $25(62.5)$ & $13(65)$ & $12(60)$ & \\
\hline & HFN & $10(25)$ & $4(20)$ & $6(30)$ & \\
\hline & Optiflow & $2(5)$ & $2(10)$ & - & \\
\hline & & Mean (SD) & Mean (SD) & Mean (SD) & $\mathrm{p}$, Ind t-test \\
\hline Birth weight (grams) & & $1411.6(395.2)$ & $1507.5(388.0)$ & $1315.80(388.1)$ & 0.788 \\
\hline $\begin{array}{l}\text { Current weight } \\
\text { (grams) }\end{array}$ & & $1481.6(369.5)$ & $1556.5(377.7)$ & $1406.85(354.8)$ & 0.204 \\
\hline $\begin{array}{l}\text { Gestational age } \\
\text { (weeks) }\end{array}$ & & $31.5(1.96)$ & $31.8(2.0)$ & $31.25(1.9)$ & 0.516 \\
\hline $\begin{array}{l}\text { Chronological age } \\
\text { (days) }\end{array}$ & & $10.1(9.8)$ & $9.4(8.2)$ & $10.80(11,4)$ & 0.660 \\
\hline
\end{tabular}


Table 2. Means of Pulse, Oxygen Saturation, and Crying Duration in the Intervention and Control Groups

\begin{tabular}{|c|c|c|c|c|c|c|c|c|}
\hline \multirow{3}{*}{ Characteristic } & \multirow{3}{*}{$\begin{array}{l}\text { Stage of } \\
\text { Puncture }\end{array}$} & \multicolumn{6}{|c|}{ Group } & \multirow{3}{*}{$\mathrm{p}$} \\
\hline & & \multicolumn{3}{|c|}{ Facilitated Tucking } & \multicolumn{3}{|c|}{ No Facilitated Tucking } & \\
\hline & & Mean & SD & Range & Mean & SD & Range & \\
\hline \multirow[t]{3}{*}{ Pulse } & Before & 145.30 & 14.183 & $120-168$ & 156.10 & 19.371 & $100-187$ & $0.053^{*}$ \\
\hline & During & 156.55 & 21.182 & $125-205$ & 180.80 & 24.827 & $148-250$ & 0.002 \\
\hline & After & 147.30 & 14.579 & $124-170$ & 165.55 & 17.209 & $130-195$ & 0.001 \\
\hline \multirow[t]{3}{*}{$\mathrm{SaO} 2$} & Before & 96.10 & 3.567 & $86-100$ & 96.05 & 3.137 & $89-100$ & $0.753 * *$ \\
\hline & During & 95.80 & 2.931 & $86-99$ & 92.35 & 4.069 & $86-99$ & 0.036 \\
\hline & After & 95.90 & 2.931 & $86-99$ & 94.05 & 2.892 & $88-98$ & 0.032 \\
\hline Crying duration & & 63.65 & 46.226 & $8-170$ & 127.35 & 68.753 & $20-240$ & $0.002^{* * *}$ \\
\hline
\end{tabular}

Note: *General Linear Model+post hoc; **Mann-Whitney; ***Independent T-Test

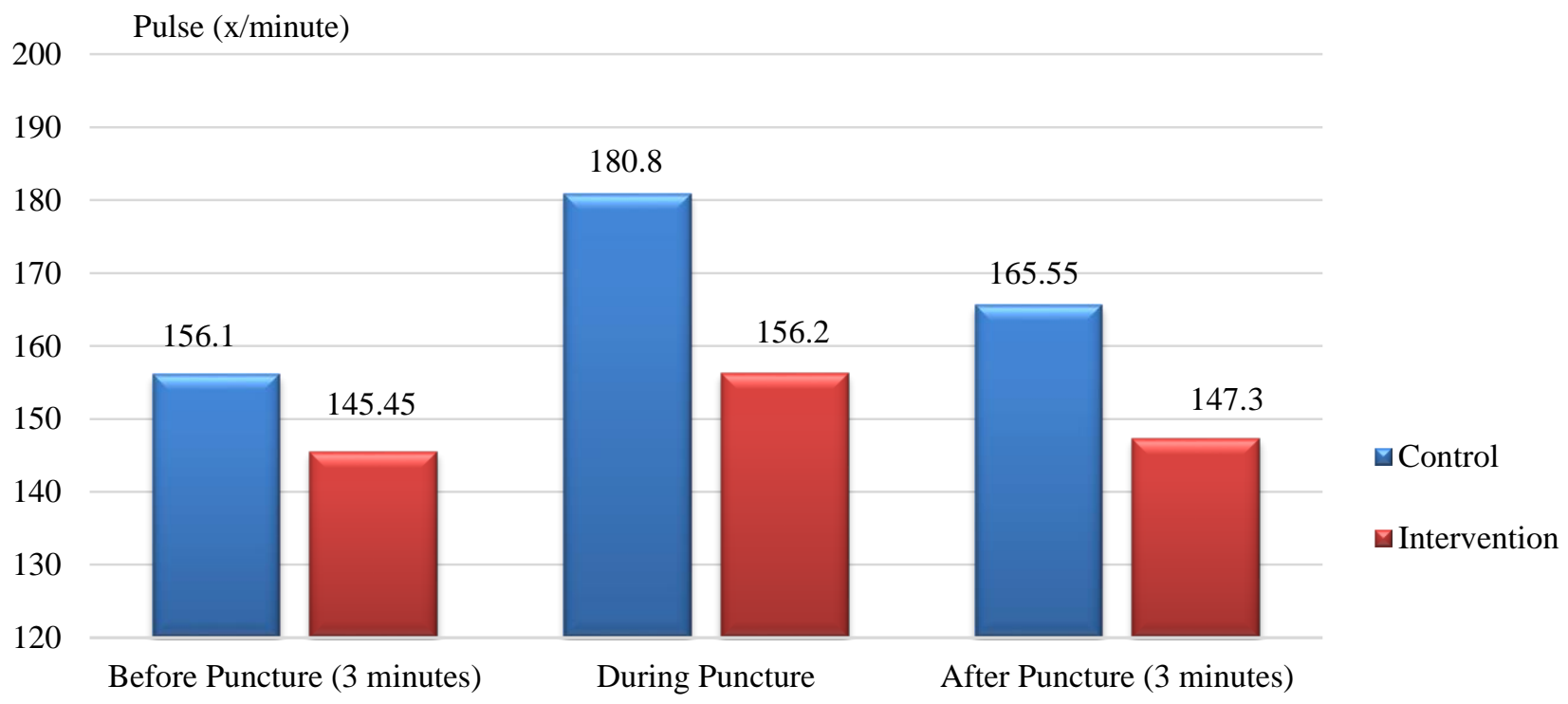

Figure1. The difference in Mean of Pulse between Intervention and Control Group

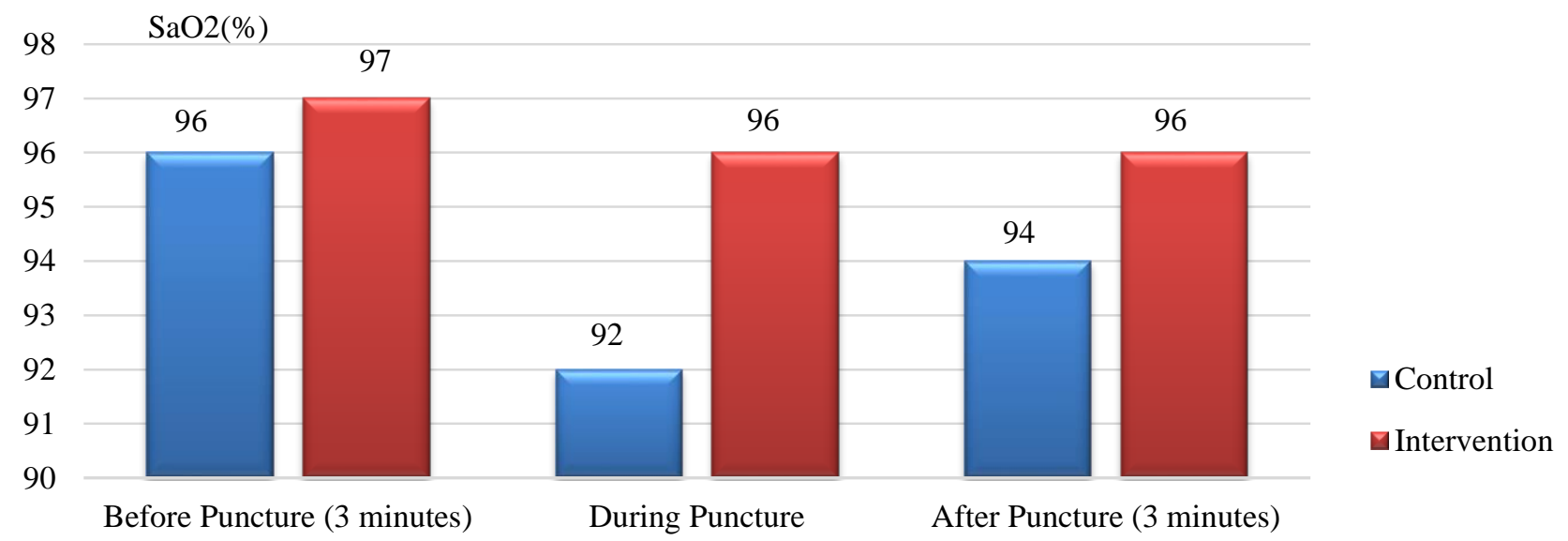

Figure 2. The difference in Mean of Oxygen Saturation between Intervention and Control Group 
highest pulse rate during puncture, and that this group had an overall higher pulse rate than the intervention group. The corresponding rate of the intervention group, which did receive facilitated tucking, immediately returned to its earlier rate following the puncture. Table 2 indicates that there was a significant difference in the mean of the pulse between the two groups during and after the puncture $(\mathrm{p}=0.002 ; \mathrm{p}=0.001, \mathrm{p}<\alpha)$.

Figure 2 suggests that the lowest oxygen saturation of the control group was during puncture. It also indicates that oxygen saturation after the puncture returned to its former value faster in the intervention group than in the control group. The intervention group also demonstrated higher overall oxygen saturation than the control group. Table 2 shows a significant difference in the mean of changes in oxygen saturation between both groups during and after puncture $(\mathrm{p}=$ 0.036: $\mathrm{p}=0.032, \mathrm{p}<\alpha$ ).

Table 2 also shows a comparison of the crying duration; the group which received facilitated tucking had a shorter duration than the group that did not receive it. The analysis results suggest a significant difference in crying duration between the two groups $(p=0.002, p<\alpha)$.

\section{Discussion}

Infants may have a higher pulse rate and lower oxygen saturation as responses to stress during blood collection procedures (Bellieni, 2012). The study findings indicate that there was a significant difference in the means of pulse and oxygen saturation during and after puncture between the group which received facilitated tucking and that which did not. This finding corresponds with that of Reyhani, Mohebi, Boskabadi, Gholami, and Ghanbarabadi (2012), who reported that there was a significant difference in pulse rate and oxygen saturation in a group which had been provided with facilitated tucking during blood collection $(\mathrm{p}=0.001)$. A study conducted by Sundaram, Shrivastava, Pandian, and Singh (2013) also revealed a significantly lower pulse rate during a 120 -second relaxation phase in infants who had received facilitated tucking during blood collection by heel stick.

Our study findings suggest that the pulse and oxygen saturation of the group provided with facilitated tucking returned more quickly to their earlier valued than those of the control group. Diego, Field, and Hernandez-Reif (2009) state that touch and positioning may facilitate an infant's physiological stability, as they increase parasympathetic activities during the relaxation phase. This claim is supported by Ramada, Almeida, and Cunha's (2013) study, which revealed that therapeutic touch promoted relaxation, reduced vital signs, and affected the basal metabolism rate in infants. Liaw, et al. (2012) reported that the application of facilitated tucking during the heel prick procedure assisted in stabilizing physiological functions and behaviors in premature neonates. Facilitated tucking helps simultaneous skin contact in the postural position, which results in a synergistic effect on pain and stabilization of the motoric and autonomic nervous system, leading to lower levels of stress (Cignacco et al., 2012). Lower stress in infants will promote their growth and development.

Premature infants have not fully developed their ability to make a flexion action independently in response to pain, which prevents them from using a self-comforting strategy to adapt to stressful and painful conditions. Facilitated tucking assists preterm infants in maintaining their movements, which leads to stability of the autonomic physiological function (Naeni, Mohagheghi, Peyrovi, \& Mehran, 2014). Smith (2012) explains that providing touch for infants is beneficial for promoting physiological and regulation stability, by maintaining the pulse rate within the normal range and improving sleep quality. The analgetic effect of touch may also be described through the oxytocinergic mechanism and mediation of $\mathrm{C}$ fiber through sensory stimuli (Hatfield, 2014; Ramada et al., 2013).

Crying is a major behavioral response to pain (Kostandy et al., 2008). Infants cry in response 
to inconveniences, including pain. Pain in hospitalized preterm infants commonly results from numerous invasive procedures, such as blood collection, and facilitated tucking is a non-pharmacological approach to relieving this pain during blood collection. The study findings indicate that the infants in the intervention group had a shorter duration of crying during blood collection than those in the control group. This result is in line with Liaw et al.'s (2012) study, which reported that there was a significantly shorter duration of crying in a group of premature infants who were provided with oral sucrose, non-nutritive sucking and facilitated tucking during the heel stick procedure than in a group who were provided with standard care.

Sundaram et al. (2013) also reported lower levels of pain in preterm infants who were provided with facilitated tucking during the heel stick procedure. A combination of facilitated tucking and music also reduced pain levels significantly and shortened the duration of crying in their intervention group (68.5 seconds) in comparison with the control group (105 seconds) (Zubaidah \& Naviati, 2015). The analysis revealed the homogeneity of both groups, so it can be assumed that infants' physiological and behavioral responses during blood collection were affected by facilitated tucking. Facilitated tucking is a type of therapeutical touch; touch is therapeutical modality which facilitates relaxation, promotes movement, enhances reflexes, and reduces anxiety and crying (Chhugani \& Sarkar, 2014).

A study conducted by Brummelte et al. (2012) claimed that infants with repeated and uncontrolled pain stimulation might lose their white matter fractional anisotropy and subcortical gray matter area of the brain. Such circumstances may lead to permanent brain damage in motoric and cognitive functions. Therefore, accurate pain assessment and appropriate pain management will provide advantages for preterm neonates, as they offer clear instructions for intervention. The fetal tucking position reduces an infant's body surface, which maintains energy expen- diture. Reducing lighting, controlling noises, and positioning are part of the developmental care that aims to enhance infants' energy and adaptation to pain stimuli (Kucukoglu et al., 2015).

The implication of the study is enriches nursing interventions, especially in perinatal units. In order to improve the quality of nursing care, perinatology nurses may apply facilitated tucking as part of the developmental care and pain management of neonates during blood collection. The intervention serves to reduce the risk of short and long-term consequences resulting from repeated painful procedures in premature infants. Chronic pain may result in weaker immune systems in neonates (Page, 2004).

The main limitation of this study was the limited number of samples involved. Only 40 participants were involved; however, the statistical analysis indicates significant differences in pulse rate, oxygen saturation and crying duration during blood collection between the intervention and control groups. Moreover, the study did not apply various standardized instruments to evaluate pain in neonates.

\section{Conclusion}

The study results suggest that facilitated tucking is effective in relieving pain in premature infants during blood collection. This is indicated by the relatively constant changes in pulse and oxygen saturation and the shorter duration of crying during blood collection in the group which was provided with facilitated tucking.

Further study should be conducted with a higher number of samples and application of various aspects of developmental care. A study with a clinical trial design should be conducted, applying standardized instruments for better results so that it can be used as a reference for hospital policies. Health facilities should enrich their pain management procedures through evidencebased practices by applying facilitated tucking as part of the standardized pain management 
procedures for neonates. Nurses and other healthcare providers should also develop their skills in neonatal pain management (HM, NN, INR).

\section{Acknowledgments}

The authors would like to express their gratitude to the Pediatric Nursing Department of the Faculty of Nursing of Universitas Indonesia, and to the board, head nurse, physicians, and nurses in the Perinatology Unit of RSUPN Ciptomangunkusumo, who provided support during the data collection.

\section{Reference}

Bellieni, C.V. (2012). Pain assessment in human fetus and infant. The American Association of Pharmaceutical Scientist Journal, 14 (3), 456-446. doi: 10.1208/s12248-012-9354

Brummelte, S., Grunau, R.E., Chau, V., Poskitt, K.J., Brant, R., Vinal, J......... Miller, S.P. (2012). Procedural pain and brain development in premature newborns. American Neurological Association, 71, 385-396. doi: 10.1002/ana.22267

Cignacco, E.L., Sellam, G., Stoffel, L., Gerull, R., Nelle, M., Anand, K.J.S., \& Engberg, S. (2012). Oral sucrose and "facilitated tucking" for repeated pain relief in preterms: A randomized Controlled Trial. Pediatrics, 129 (2), 299-308. doi: 10.1542/peds.2011-1879

Chhugani, M., \& Sarkar, S. (2014). Therapeutic touch modalities and premature neonates's health outcome: A literature review. Neonatal Biology, 3 (148), 1-3. doi. 10.4172/ 2167-0897.1000148

Diego, M.A., Field, T., \& Hernandez-Reif, M. (2009). Procedural pain heart rate responses in massaged preterm infants. Infants Behavioural Development, 32 (2), 226-229. doi: 10.1016/j.infbeh.2008.12.001

Fernandes, A., Campbell-Yeo, M., \& Johnston, C.C. (2011). Procedural pain management for neonates using non-pharmacological strategies: Part 1: Sensorial interventions. Advances in
Neonatal Care, 11 (4), 235-241.doi: 10.1097 /ANC.0b013e318225a2c2

Hatfield, L.A. (2014). Neonatal pain: What's age got to do with it? Surgical Neurology International, 5 (13), s479-s489. doi: 10.4103/ 2152-7806.144630

Jaberi, E., \& Raksana, M. (2017). A study on preterm births during 2013-2015, shiraz, iran. Journal of Obstetrics and Gynaecology, 38 (1), 22-26. doi: 10.1080/01443615.2017.132 2565

Johnston, C.C., Fernandes, A.M., \& Campbell-Yeo, M. (2011). Pain in neonates is different. Pain, 152 (3), S63-S73. doi: 10.1016/j.pain.2010. 10.008

Konstandy, R., Xiaomei, C., Abouelfettoh, A., Bronson, C., Stankus, A., \& Ludington, S.M. (2008). Effect of kangaroo skin care (skin contact) on crying response to pain in preterm neonates. Pain Management of Nursing, 9 (2), 55-65. doi: 10.1016/j.pmn.2007.11.004

Kostovic, I., \& Judas, M. (2010). The development of the subplate and thalamocortical connections in the human fetal brain. Acta Paediatrica, 99 (8), 1119-1127. doi: 10.1111/j.1651-222 7.2010.01811.x

Kucukoglu, S., Kurt, S., \& Aytekin, A. (2015). The effect of the facilitated tucking position in reducing vaccination-induced pain in newborns. Italian Journal of Pediatrics, 41, 61. http://doi.org/10.1186/s13052-015-0168-9

Lago, P., Garetti, E., Merazzi, D., Pieragostini, L., Ancora, G., Pirelli, A., \& Bellieni, C. V. (2009). Guidelines for procedural pain in the newborn. Acta Paediatrica (Oslo, Norway: 1992), 98 (6), 932-939. http://doi.org/10. $1111 /$ j.1651-2227.2009.01291.x

Lawn, J.E., Davaidge, R., Paul, V.K., Xylander, S.V., Johson, J.D.G., Costello, A. ...... Molyneux, L. (2013). Born too soon: Care for the preterm baby. Reproductive Health, 10 (1), 1-19. doi: 10.1186/1742-4755-10-S1-S5

Liaw, J.J., Yang, L., Lee, C.M., Fan, H.C., Chang, Y.C., \& Cheng, L.P. (2012). Effects of 
combined use of non-nutritive sucking, oral sucrose, and facilitated tucking on infant behavioural states across heel-stick procedures: A prospective, randomized controlled trial. International Journal of Nursing Studies, 50 (7), 883-894. doi: 10.1016/j.ijnurstu.2012. 08.021

Marchant, A. (2014). Neonatal do not feel pain: A critical review of the evidence. Bioscience Horizons, 7, 1-9. doi: 10.1093/biohorizons/ hzu006

Martin, S.W., Dias, F.S., Enumo, S.R.F., \& de Paula, K.M.P. (2013). Pain assessment and control by nurses of neonatal intensive care unit. Revista do Instituto de Medicina Tropical de Sao Paulo, 14 (1), 21-26.doi: 10.1590/ S1806-00132013000100006

Naeni, M.A., Mohagheghi, P., Peyrovi, H., \& Mehran, A. (2014). The effect of facilitated tucking during endotracheal suctioning on procedural pain in preterm neonates: A randomized controlled crossover study. Global Journal of Health Science, 6 (4), 278-284. doi: 10.5539/gjhs.v6n40278

Page, G.G. (2004). Are there long-term consequences of pain in newborn or very young infants? The Journal of Perinatal Education, 13 (3), 10-17. http://doi.org/10.1624/105812404X1 725

Ramada, N.C.O., Almeida, F.A., \& Cunha, M.L.R. (2013). Therapeutic touch: influence on vital signs of newborns. Einstein, 11 (4), 421-425.
http://doi.org/10.1590/S1679-450820130004 00003

Reyhani, T., Aemmi, S.Z., Mohebbi, T., \& Boskabadi, H. (2014). The effect of facilitated tucking (FT) during venipuncture on duration of crying in preterm infants. International Journal of Pediatrics, 12 (2), 431-435.

Reyhani, T., Mohebbi, T., Boskabadi, H., Gholami, H., \& Ghanbarabadi, G.V. (2012). The effect of facilitated tucking during venipuncture on pain and physiological parameters in preterm infants. Evidence Based Care Journal, 2 (2), 47-55. doi: 10.22038/EBCJ.2012.399

Smith, J.R. (2012). Comforting touch in the very preterm hospitalized infant: An integrative review. Advances in Neonatal Care, 12 (6), 349-365. doi: 10.1097/ANC.0b013e3182609 3 ee

Sundaram, B., Shrivastava, S., Pandian, J.S., \& Singh, V.P. (2013). Facilitated tucking on pain in pre-term newborns during neonatal intensive care: A single blinded randomized controlled cross-over pilot trial. Journal of Pediatric Rehabilitation Medicine, 6 (1),1927. doi: 10.3233/PRM-130233

Zubaidah, Z., \& Naviati, E. (2015). Pengaruh facilitated tucking dan musik terhadap respon nyeri bayi prematur ketika pengambilan darah. Jurnal Keperawatan Soedirman, 10 (2), 94-104. http://dx.doi.org/10.20884/1.jks. 2015.10.2.603 